UDK 625.315.529

\author{
V.P. MAKHNIY, M.M. BEREZOVSKIY, O.V. KINZERSKA, I.M. SENKO
}

\title{
EDGE LUMINESCENCE OF ZINC SELENIDE CRYSTALS WITH IMPURITIES OF RARE-EARTH ELEMENTS
}

\author{
Yuriy Fedkovych Chernivtsi National University \\ 2 Kotsyubunskogo str., Chernivtsi, Ukraine
}

\begin{abstract}
Анотація. Експериментально показано, що легування бездомішкових розплавних кристалів $\mathrm{ZnSe}$ рядом рідкісноземельних елементів (Ce, $\mathrm{Gd}$ та $\mathrm{Yb}$ ) викликають «ефект очищення», який проявляється в значному «придушенні» низькоенергетичної та посиленні краєвої смуги люмінесценції.

Ключові слова: селенід цинку, рідкісноземельні елементи, люмінесценція, точкові дефекти

Аннотация. Экспериментально показано, что легирование беспримесных расплавных кристаллов ZnSe рядом редкоземельных элементов (Ce, Gd та $\mathrm{Yb}$ ) вызывают «эффект очищения» который проявляется в значительном подавлении низкоэнергетической и усилению краевой полосы люминесценции.

Ключевые слова: селенид цинка, редкоземельные элементы, люминесценция, точечные дефекты. Abstract. It was experimentally shown that doping of pure ZnSe melt crystals by a number of rare-earth elements $(\mathrm{Ce}, \mathrm{Gd}$ and $\mathrm{Yb})$ causes a «purification effect», which is manifested in a significant suppression of low-energy and increase of edge luminescence band.

Key words: zinc selenide, rare-earth elements, point defects.

DOI: $10.31649 / 1681-7893-2018-35-1-89-92$
\end{abstract}

\section{INTRODUCTION}

Despite the large band gap ( $E_{g} \square 2.7 \mathrm{eV}$ at $300 \mathrm{~K}$ ) and the high probability of radiative recombination, zinc selenide today, unfortunately, continues to be a promising material for creating blue-blue LEDs. A large variety of intrinsic and uncontrolled point defects, as well as their associates, leading to self-compensation effects are the main reasons for the controlled production of this compound with the required parameters and characteristics [1]. These problems are especially serious for the most common bulk ZnSe crystals grown by the Bridgman-Stockbarger method from a melt under an inert gas pressure [2]. We note that it is precisely because of the diversity of the point defects noted above that the physical properties of both pure crystals and crystals doped during the growth process are, in the overwhelming majority of cases, quite far from the expected ones. For their correction, various additional technological operations are used, which usually consist in conducting thermal annealing in vacuum or in pairs of its own components, as well as doping with simple or rarely used impurities - isovalent, amphoteric, 3d-elements [3,4]. These also include rare-earth elements (REE), the introduction of which into semiconductor materials causes a "purification effect", which was considered in detail in [5] using the example of III-V compounds. Regarding II-VI compounds, including those for ZnSe, these issues, unfortunately, are studied extremely little.

Meanwhile, in a number of works [5,6], it was convincingly shown that doping ZnSe crystals during their growth with ytterbium $\mathrm{Yb}$, one of the representatives of REE, causes a decrease in the concentration of background donor impurities and an increase in the efficiency of exciton radiation. Later, similar effects were also observed in melt $\mathrm{ZnSe}$ crystals after the introduction of $\mathrm{Yb}$ impurity from the vapor phase into them [7]. In this work, we study the effect of a series of REEs $(\mathrm{Ce}, \mathrm{Gd}, \mathrm{Yb})$ on the formation of the edge luminescence band of pure melt crystals and its temperature evolution.

\section{SAMPLES AND INVESTIGATION TECHNIQUES}

Base substrates of $4 \times 4 \times 1 \mathrm{~mm}^{3}$ size were cut from a bulk ZnSe crystal grown by the BridgmanStockbarger method from a melt of stoichiometric composition. REE diffusion was carried out in a vacuum ampoule up to $10^{-4}$ Torr and a sealed quartz ampoule, at one end of which there was a substrate, and at the opposite end - a charge. The latter contained weighed particles of crushed $\mathrm{Ce}, \mathrm{Gd}$, or Yb and elementary Se, which by creating a back pressure prevented erosion of the surface of the samples and promoted the entry of $\mathrm{REE}$ atoms into the cationic zinc sublattice of $\mathrm{ZnSe}$. Note that the surface of the samples after diffusion remains the same specular as before loading into the ampoules, which was obtained by etching the base substrates in a $\mathrm{CrO}_{3}: \mathrm{HCl}=2: 3$ solution. This fact allows the use of doped substrates for further measurements without the use of any additional treatments. 
The photoluminescence (PL) spectra $N_{\omega}$ were measured on a universal complex containing a diffraction monochromator of the type MDR-23 and a standard synchro-detection system. The radiation source was a nitrogen laser with a wavelength of $\lambda_{m} \square 0.337 \mu \mathrm{m}$, and the spectra were recorded automatically on a recorder. The temperature changed and was maintained with an accuracy of $\pm 0.5 \mathrm{~K}$ in the range of 300-500 K.

\section{RESULTS DISCUSSION}

A typical PL spectrum of basic ZnSe substrates is shown in Fig. 1 and consists of two bands - redorange (R) and blue (B), curve 1. The first band is caused by recombination on donor - acceptor pairs (DAP), which include negative double-charge $V_{Z n}{ }^{\prime \prime}$ zinc vacancies and positive single-charge selenium vacancies $V_{S e}^{\bullet}$. According to [8], their concentration in melt ZnSe crystals is rather high $\sim 5 \cdot 10^{21} \mathrm{~cm}^{-3}$, and the concentration of associates $\left(V_{Z n}{ }^{\prime \prime} V_{S e}^{\bullet}\right)$ is $\sim 3 \cdot 10^{16} \mathrm{~cm}^{-3}$. Note that the ratio between the intensities of the $\mathrm{R}$ and $\mathrm{B}$ bands also depends on the level of excitation $L$, the increase in which causes increased edge radiation.

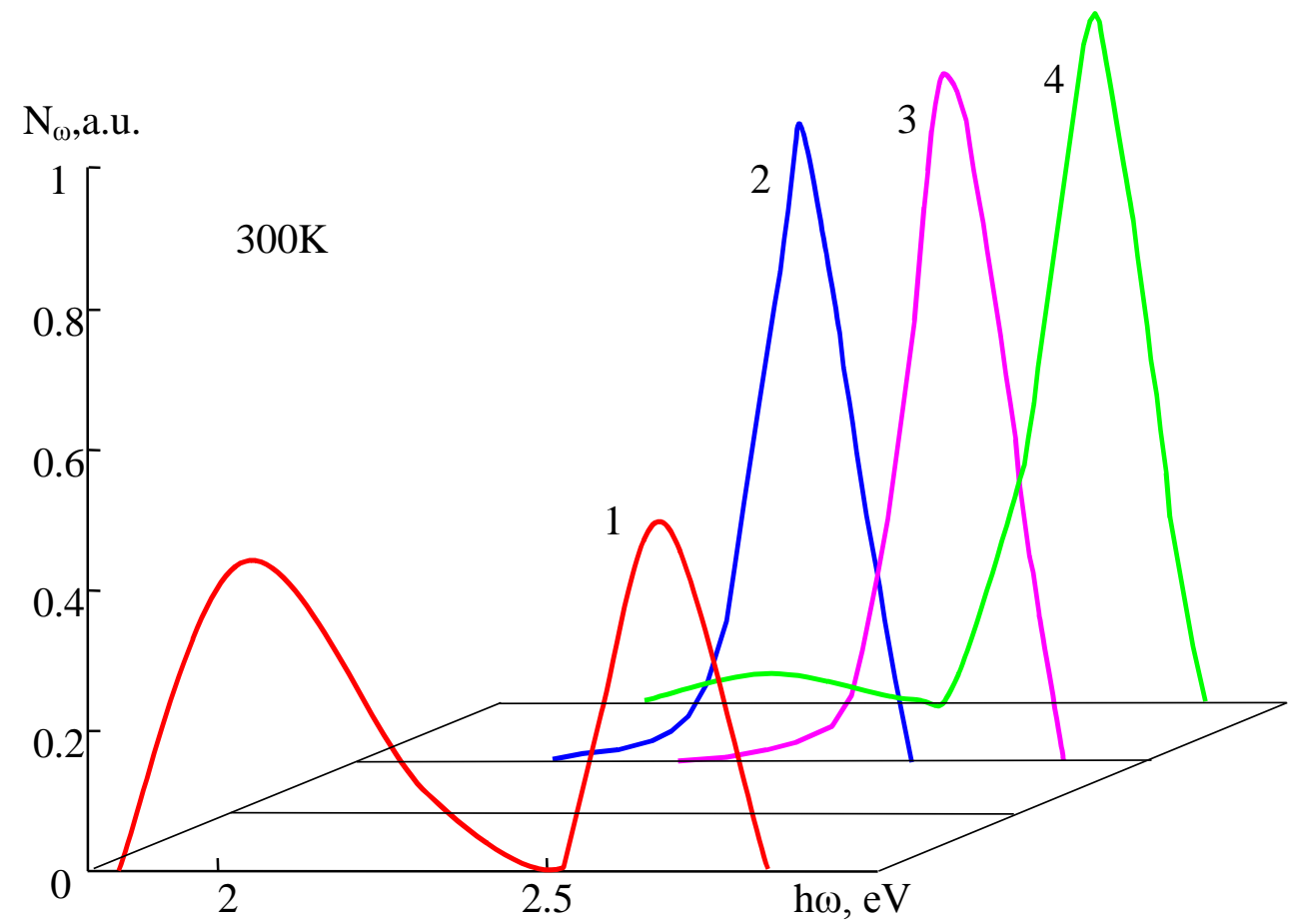

Fig. 1 Typical photoluminescence spectra of base $\mathrm{ZnSe}(1)$, and doped with various rare-earth elements $\mathrm{Yb}(2)$, Gd (3), Ce (4) crystals

A detailed analysis of the B band shows that it is the sum of two elementary bands, the first of which is due to the recombination of free holes with electrons bound at the centers $V_{S e}$, and the second to interband transitions [8]. We also pay attention to the fact that the R-band is present in the PL spectra in molten pure $\mathrm{ZnSe}$ crystals even at $77 \mathrm{~K}$ and at the maximum $\left(\sim 10^{18} \mathrm{kV} / \mathrm{s}\right)$ excitation level.

A completely different scheme of recombination processes is realized in substrates doped with REE, typical PL spectra are shown in Fig. 1, curves 2-4. The most characteristic of them is a sharp decrease in the proportion of red-orange radiation as compared to edge luminescence, which may be a consequence of the "effect of purification" of samples from the centers responsible for the formation of the R-band. These, in our opinion, are zinc vacancies that are "healed" by REE atoms, as a result of which the concentration of donor acceptor pairs is reduced $\left(V_{Z n}{ }^{\prime \prime} V_{S e}^{\bullet}\right)$. The release of selenium vacancies from DAP, which serve as small donors ( $E_{d} \square 0.03 \mathrm{eV}[8]$ ), causes an increase in the concentration of these local centers. The confirmation of this is, first of all, an increase in the intensity $I_{B}$ of the B band, which, after doping with REE samples, is large compared with the initial substrates.

Meanwhile, the ratio of the intensity of doped substrates $I_{B l}$ to the value $I_{B b}$ measured at the same temperature and level of excitation depends on the type of REE, as illustrated in Fig. 2 (a-d). This may be due to both the difference in solubilities of the REE used ( $\mathrm{Ce}, \mathrm{Gd}$, and $\mathrm{Yb}$ ) in zinc selenide, as well as a consequence of the effect of "lanthanoid compression". 
$\mathrm{T}, \mathrm{K}$

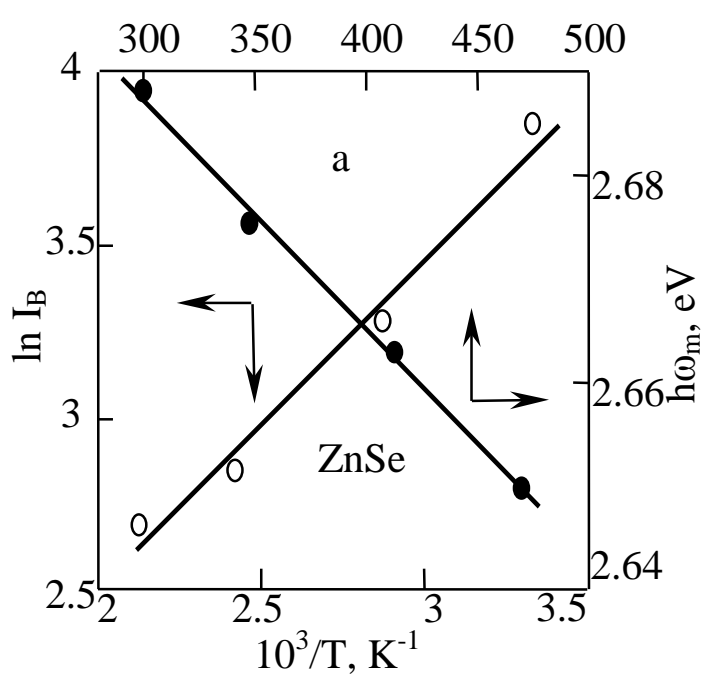

$\mathrm{T}, \mathrm{K}$

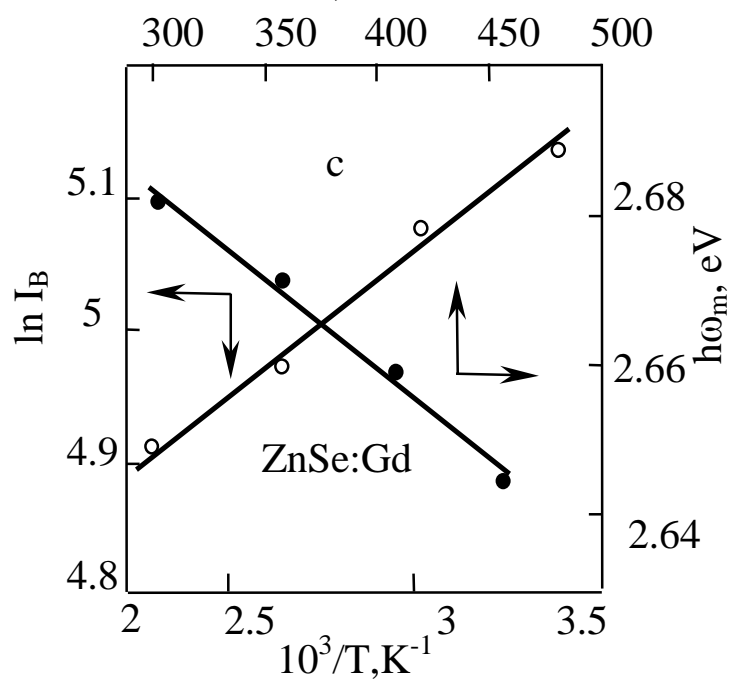

$\mathrm{T}, \mathrm{K}$

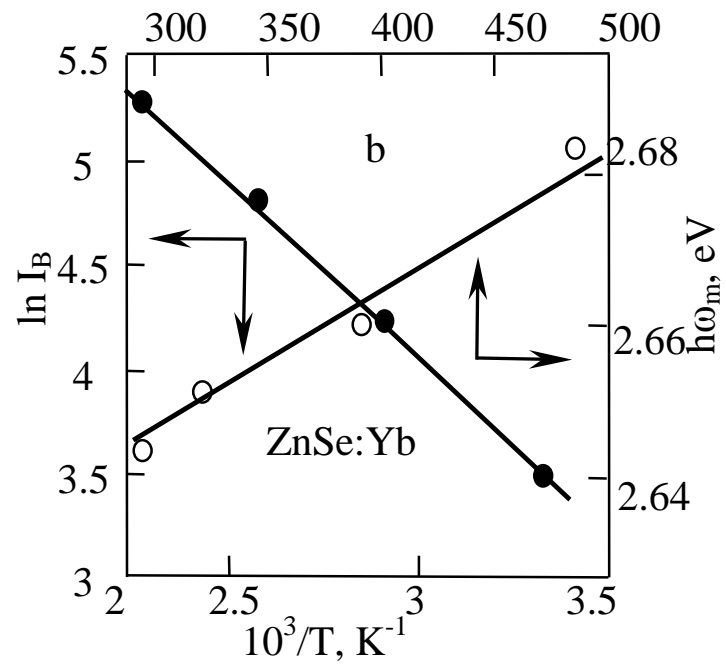

$\mathrm{T}, \mathrm{K}$

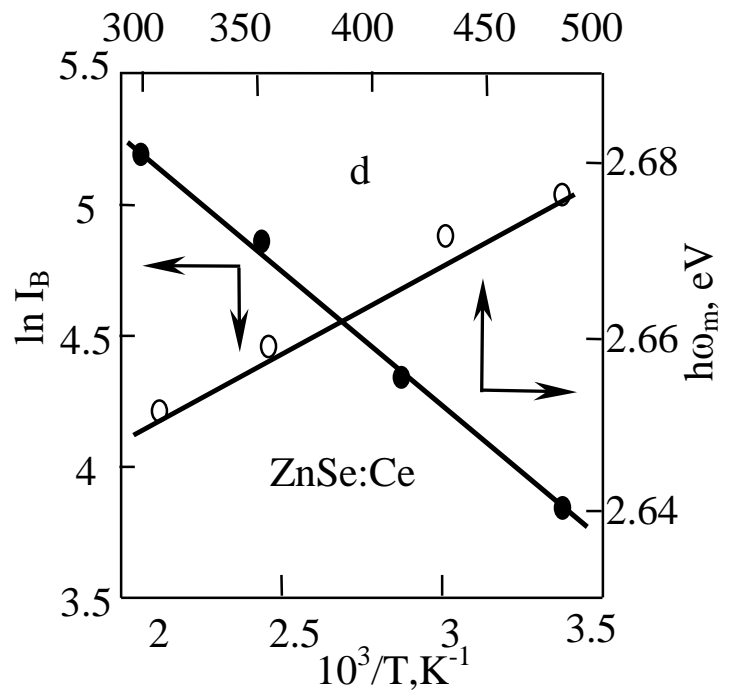

Fig. 2 Temperature dependences of the intensities $I_{B}$ and maximums $\hbar \omega_{m}$ of the B-band of the base and doped

ZnSe substrates

The latter stands in a decrease in the ionic radius of rare-earth elements with an increase in their sequence number, which is associated with an increase in the energy of attraction of external valence electrons to the nucleus. In this regard, it can be assumed that the least effective "healing" of zinc vacancies should be carried out by cerium atoms, the ionic radius of which is approximately 1.2 times the radius of the ytterbium ion [9]. This conclusion is indirectly confirmed by the presence of the ZnSe:Ce R bands in the PL spectrum, which is absent in samples with $\mathrm{Yb}$ and $\mathrm{Gd}$ impurities, fig. 1. It follows from the above that the diffusion of REE into pure ZnSe rare-earth melt crystals causes a rearrangement of an ensemble of intrinsic point defects, which manifests itself in a change in the ratio between the intensities of the red-orange and blue bands, and in favor of the latter for doped samples. On the other hand, almost the same form of the B band in all objects of research indicates the same recombination mechanisms (impurity and interband), although the ratio between them is determined by the presence and type of REE in the sample. This is indirectly confirmed by the difference in temperature dependences of the intensities $I_{B}$ and maximum $\hbar \omega_{m}$ of the B-band of the substrates shown in fig. 2 (a-d). 


\section{CONCLUSIONS}

Thus, the above results show that the doping of pure ZnSe melt crystals with rare-earth elements causes "quenching" of low-energy and "heating up" of the edge bands of luminescence. Further studies should be aimed at establishing and analyzing the mechanisms of defect formation and radiative recombination in connection with the technological conditions of doping of rare-type zinc selenide.

\section{REFERENCES}

1. Георгобиани А.Н., Шейнкман М.К. (1986). Физика соединений $\mathrm{A}^{\mathrm{II}} \mathrm{B}^{\mathrm{VI}}$. М:Наука.

2. Кульчицький Н.А., Наумов А.В. (2014) Современные оптоэлектронные приборы на основе селенида цинка. Наноинжерения, 11, 19-27.

3. Сльотов М.M. (2007) Механізми люмінесценції в дифузійних шарах широкозонних II-VI напівпровідників: Дис....док. фіз.-мат. наук. Чернівці.

4. Кінзерська О.В. (2012) Фізичні властивості кристалів селеніду цинку, легованих перехідними металами: Дис....канд. фіз.-мат. наук. Чернівці.

5. Гореленюк А.Т., Каманин А.В., Шмидт Н.М. (2003) Редкоземельные элементы в технологии соединений $\mathrm{A}^{\mathrm{III}} \mathrm{B}^{\mathrm{V}}$ и приборов на их основе. ФТП, 37, 8, 922-940.

6. Radevici I., Sushkevich K., Huhtinen H., Nedeoglo D., Paturi P. (2015). Influence of the ytterbium doping technique on the luminescent properties of ZnSe single crystals. J. Lumin, 158, 236-242.

7. Makniy V.P., Kinzerska O.V., Senko I.M. (2017). «Purification effects» in zinc selsnide crystals doped with ytterbium from vapor phase. Telecom. and Radio Engineering, 75, 3, 279-284.

8. Ткаченко I.В. (2005) Механізми дефектоутворення та люмінесценції у бездомішкових і легованих телуром кристалах селеніду цинку: Дис....канд. фіз.-мат. наук. Чернівці.

9. Ахметов Н. С. (2001). Общая и неорганическая химия. М.:Высшая школа.

Надійшла до редакції 15.04.2018

ВІКТОР ПЕТРОВИЧ МАХНІЙ - д.ф.-м.н, професор кафедри оптики та ВПС, Чернівецький національний університет імені Юрія Федьковича, м.Чернівці, Україна

МИХАЙЛО МИХАЙЛОВИЧ БЕРЕЗОВСБКИЙ - к.ф.-м.н, доцент кафедри оптики та ВПС, Чернівецький національний університет імені Юрія Федьковича, м.Чернівці, Україна

ОКСАНА ВОЛОДИМИРІВНА КІНЗЕРСЬКА - к.ф.-м.н, асистент кафедри фізики напівпровідників i наноструктур, Чернівецький національний університет імені Юрія Федьковича, м.Чернівці, Україна

ІЛЛЯ МИХАЙЛОВИЧ СЕНКО - аспірант кафедри фізики напівпровідників і наноструктур, Чернівецький національний університет імені Юрія Федьковича, м.Чернівці, Україна 